\title{
The Economy and Possibility of Energy Community in Finnish Solar Energy Production
}

\author{
Juha Korpijärvi \\ Electricity and Automation \\ South-Eastern Finland University of \\ Applied Sciences \\ Mikkeli, Finland \\ juha-korpijarvi@xamk.fi
}

\author{
Riikka Tanskanen \\ Forest, the Environment and Energy \\ South-Eastern Finland University of \\ Applied Sciences \\ Mikkeli, Finland
}

\begin{abstract}
The amount of solar energy production in the electricity distribution networks is increasing. This is due to technology conventionalisation, which in turn has led to solar panels becoming more affordable. The aim of this study was to analyse real-life, domestic electricity consumption to determine whether changes in current Finnish legislation could enable new economic possibilities in the use of solar power. The study data consisted of electricity consumption data, that has been digitally monitored on hourly basis. The hypothesis was that a group of individual solar power producers could benefit from a common system, as compared to each group member having a solar production system of their own. In Finland, private households benefit from solar energy production via savings on both energy and transmission costs, as well as the taxes included in these costs. It is economical to install and utilise solar energy even though the price of solar energy is higher than that of fossil fuels. In this study, the economies of energy communities with larger solar panel units were compared with individual households with small-scale solar production units. As a conclusion, the study results indicate that the overall economy of solar energy would be better if the solar panels in the network were installed in larger units. However, this possibility requires energy communities to be legally permitted in Finland.
\end{abstract}

\section{Keywords—solar energy, energy community, economy}

\section{INTRODUCTION}

Solar energy has increased in popularity during recent years in Finland, although the share of solar energy nationally is only around 0.07 per cent in the total energy production [1]. However, the aim due to climate change should be increasingly towards renewable energies whilst reducing the use of fossil fuels [2]. To reduce carbon emissions in the European Union, EU legislation is currently moving towards removing legal, bureaucratic and technical barriers that have hindered the transition to the use of renewable energy sources [3]. Furthermore, there is a strong indication that private sector representatives in Finland would be increasingly interested in investing in renewable energies such as solar energy $[2,4,5]$. In contrast, fossil fuels are still subsidised in the world by 5.8 per cent of Gross Domestic Product globally [2]. Therefore, the Finnish government should aim at promoting the use of renewable energies in the long term, since the desirable changes in energy production will be led by private investments [2]. Currently, private households and other private sector representatives invest in solar energy mainly because it is

Funded by the European Union, the Russian Federation and the Republic of Finland (CBC 2014-2020). becoming more affordable and available [5].

In Finland, private households pay about 15 cents per $\mathrm{kWh}$ for electricity consumed [6]. The price consists of three main components that account for roughly one third each. These price components are the price of energy, transmission costs and taxes. [7] By producing and using solar energy, a private household can avoid paying the majority of these price components to the electricity provider. The only downside is that it is relatively expensive to purchase a small solar energy production unit [8]. Therefore, this study case is aimed at researching whether a larger, centralised and shared solar production unit could be financially beneficial to both individual households and the electricity network.

\section{MATERIALS AND METHODS}

\section{A. Solar energy production modelling}

In Finland, solar energy production varies strongly depending on the time of the day and year. However, the summertime with its long daylight hours and favourable outdoor temperatures, makes the Finnish climate more suitable for solar energy production than is commonly thought. [5] In this study, the daily and seasonal variation of the solar radiation was considered by creating a model where the hourly production of the solar panels (in $\mathrm{kWh}$ ) could be studied. In addition, solar energy production is dependent on the size of the solar panels $(\mathrm{kW})$, as well as the cloudiness of the day. Therefore, the cloudiness was modelled using a random factor, so that the utilisation period of the solar power was around 800 hours per year.

\section{B. Household electricity consumption cases}

In this study, household electricity consumption was analysed using the digitally monitored hourly electricity consumption of six real-life household cases $[9,10,11,12,13]$. Each of the electricity consumption cases represents an example of domestic electricity and buildings in the South Savo (Finland) area. The study group was purposely chosen as heterogonous in building size, number of inhabitants, heating system and type of use. The studied building sizes varied between 67 and $167 \mathrm{~m}^{2}$, the number of inhabitants varied between 2 and 5, and the heating systems represented were electric heating, district heating and thermal heating. Four of the study cases were private family houses. The fifth study case was a household with a separate livestock building connected to the households' electric consumption network. Lastly, the sixth study case was a privately owned summer cottage. Both the fifth and sixth study cases are 
typical of the South Savo area and are therefore of value to the study.

The common denominator for the study household cases was that they do not yet have solar energy production. Furthermore, in this study they are considered as neighbours, when in real life they are not situated next to each other. The shared solar electricity system would require them to be neighbours to be able to utilise the solar electricity directly on site.

The hourly production model for solar radiation and production (described in Section A) could be compared with the electricity consumption profile of the study case households. Every household in Finland can obtain its own electricity consumption as digitally monitored hourly data. The data is created by remote-controlled energy consumption meters, which are obligatory in Finland [14]. By comparing these two sets of data, it was possible to determine how much of the produced solar energy each study case would be able to utilise, and what portion of the energy produced could be sold to the electricity network.

\section{Solar power system price components considered}

The investment price for solar power production depends on the size of the production unit. The price of the system (Euros per $\mathrm{kW}$ ) decreases with the increase in system size. The investment price for small-scale units is presented in Figure 1, and for larger-scale units in Figure 2. The system prices represent those typical of the South Savo area $[4,15]$.

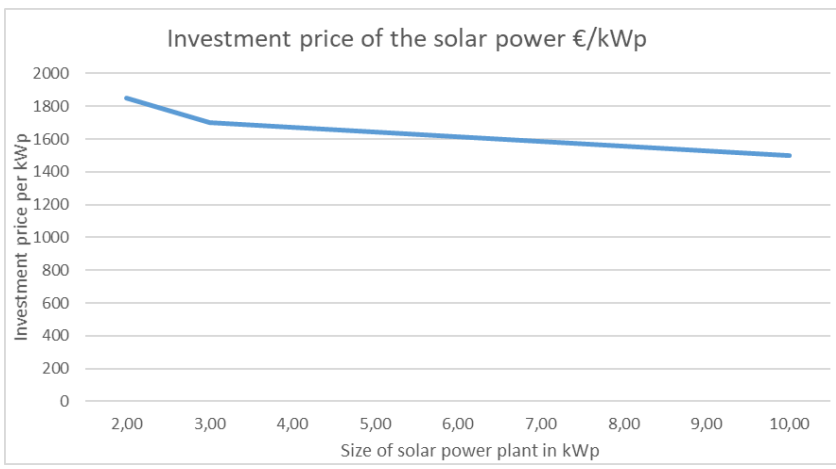

Fig. 1. The investment price for a small-scale solar power plant in Euros per $\mathrm{kWp}$ according to the size of the solar unit in $\mathrm{kW}[4,15]$.

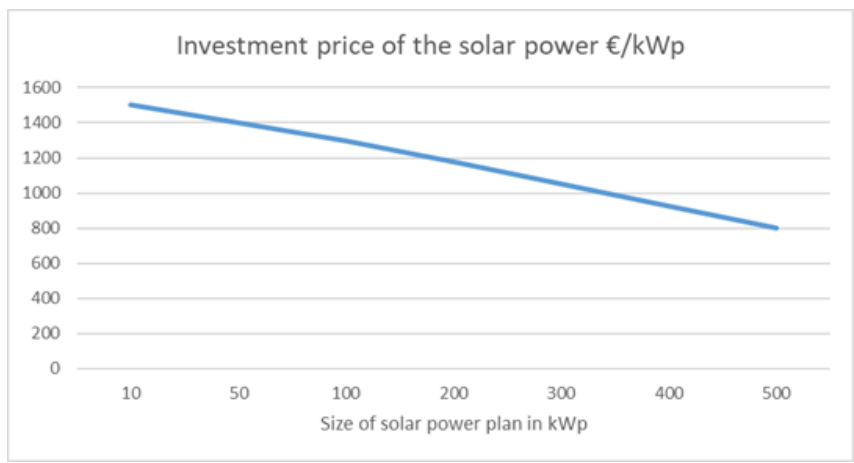

Fig. 2. The investment price for a large-scale solar power plant in Euros per $\mathrm{kWp}$ according to the size of the solar unit in $\mathrm{kW}[4,15]$.

The electricity price for domestic users in Finland includes three price components: energy costs, transmission costs and taxes [16]. Each of these components represents about one third of the total price which the domestic electricity user pays for the consumed electricity. Furthermore, each of these price components consists of both a flat rate and a consumption-dependent part [16]. The flat rate share of the costs must be paid in any case. Therefore, the economic value of solar energy for the households can be considered as 8.5 cent $/ \mathrm{kWh}$ [4]. In addition, the maintenance costs for the solar panels in this study have been considered as $1.5 \mathrm{cent} / \mathrm{kWh}$ [17]. Furthermore, the economic value of the solar energy may be considered as 3,5 cent $/ \mathrm{kWh}$ for the domestic solar producer, when excess energy is sold back to the network [18]. The total cost of the electricity provided by the electricity network, may be considered as 15 cent $/ \mathrm{kWh}$ [6]. In the calculations, however, the value of produced solar energy is considered as $8.5 \mathrm{cent} / \mathrm{kWh}$, since the difference is the flat rate [7].

The solar energy produced and utilised in a household naturally reduces the amount of electricity needed and bought from the electricity provider via the electricity network. Furthermore, due to energy production taxation in Finland, the share of the electricity that needs to be sold to the network should be as low as possible [17]. The household producing solar energy should not produce excess energy, since it cannot benefit from the sold energy economically. The price of solar energy, when sold to the network, is less than half of that of the energy that the household uses itself to replace purchasable electricity. [18]

The size of the solar power unit for household users depends on the electricity consumption profile. The analysis would have not been possible to make without modern digital methods, where the electricity consumption was digitally monitored by the hour. The critical issue is to match the consumption and production as closely as possible. As stated above, solar electricity sold back to network is not profitable for the household producer due to the lower selling price. Therefore, in this study, the solar panel size was chosen so that at least 70 per cent of the produced energy could be used in the household, and the remaining 30 per cent could be sold back to the electricity network [16]. However, all the study cases were set with a minimum of a 2 $\mathrm{kW}$ solar system.

\section{RESULTS}

The aim of this study was to research a group of households to determine whether an energy community in solar energy production would be more economically favourable for the households as compared to each having an individual solar panel system of their own. To make the needed comparison possible, both cases and their results are demonstrated in the following.

\section{A. Household cases with individual solar energy systems}

The study group of six South Savo household cases is presented in Table I, where they are numbered from 1 to 6 as individual consumption cases. Table I includes electricity consumption, maximum power, building surface area and source of heating. $[9,10,11,12,13]$. 
TABLE I. HOUSEHOLD CASES ANALYSED IN THE STUDY

\begin{tabular}{|c|c|c|c|c|}
\hline Case & $\begin{array}{c}\text { Yearly } \\
\text { electricity } \\
\text { consumption }\end{array}$ & $\begin{array}{c}\text { Maximum } \\
\text { power }\end{array}$ & $\begin{array}{c}\text { Surface } \\
\text { area }\end{array}$ & Heating system \\
\hline 1 & $21554 \mathrm{kWh}$ & $12.91 \mathrm{~kW}$ & $130 \mathrm{~m}^{2}$ & $\begin{array}{c}\text { Thermal } \\
\text { heating }\end{array}$ \\
\hline 2 & $13909 \mathrm{kWh}$ & $7.32 \mathrm{~kW}$ & $122 \mathrm{~m}^{2}$ & $\begin{array}{l}\text { Electric } \\
\text { heating }\end{array}$ \\
\hline 3 & $14664 \mathrm{kWh}$ & $6.68 \mathrm{~kW}$ & $167 \mathrm{~m}^{2}$ & $\begin{array}{l}\text { Thermal } \\
\text { heating }\end{array}$ \\
\hline 4 & $8696 \mathrm{kWh}$ & $8.13 \mathrm{~kW}$ & $67 \mathrm{~m}^{2}$ & $\begin{array}{l}\text { Electric } \\
\text { heating }\end{array}$ \\
\hline 5 & $15549 \mathrm{kWh}$ & $7.23 \mathrm{~kW}$ & $83 \mathrm{~m}^{2}$ & $\begin{array}{l}\text { Electric } \\
\text { heating }\end{array}$ \\
\hline 6 & $4497 \mathrm{kWh}$ & $4.33 \mathrm{~kW}$ & $120 \mathrm{~m}^{2}$ & $\begin{array}{l}\text { District } \\
\text { heating }\end{array}$ \\
\hline
\end{tabular}

Table I demonstrates that the study cases vary, with annual electricity consumption between 4497 and 21554 $\mathrm{kWh}$. However, to be able to study the solar energy production in each case, the basic information for the studied household cases has been utilised to obtain the information on what would be a suitable size for each individual solar energy system. The results are presented in Table II, where the minimum size for the solar panel system was considered to be $2 \mathrm{~kW}$.

TABLE II. CAPACITY OF THE HOUSEHOLDS TO USE SOLAR ENERGY

\begin{tabular}{|c|c|c|c|}
\hline Case & $\begin{array}{c}\text { Solar panel } \\
\text { size }\end{array}$ & $\begin{array}{c}\text { Solar } \\
\text { energy } \\
\text { production }\end{array}$ & $\begin{array}{c}\text { Share used in } \\
\text { households own } \\
\text { consumption }\end{array}$ \\
\hline 1 & $3 \mathrm{~kW}$ & $2384 \mathrm{kWh}$ & $71 \%$ \\
\hline 2 & $2 \mathrm{~kW}$ & $1617 \mathrm{kWh}$ & $72 \%$ \\
\hline 3 & $3 \mathrm{~kW}$ & $2390 \mathrm{kWh}$ & $74 \%$ \\
\hline 4 & $2 \mathrm{~kW}$ & $1620 \mathrm{kWh}$ & $48 \%$ \\
\hline 5 & $4 \mathrm{~kW}$ & $3130 \mathrm{kWh}$ & $72 \%$ \\
\hline 6 & $2 \mathrm{~kW}$ & $1594 \mathrm{kWh}$ & $45 \%$ \\
\hline
\end{tabular}

Table II lists the solar system sizes, the modelled solar energy production and the percentage of the energy being utilised in the household itself for each study case. It should be noted that the simulation for cloudiness using a random factor is the reason why the same sized systems have produced different amounts of energy. However, each of the cases has had a maximum load between 797-810 hours per year.

The results in Table II indicate that cases 1, 2, 3 and 5 would be able to use more than 70 per cent of the solar energy in their households, whereas cases 4 and 6 could only utilise less than 50 per cent. This ratio indicates that the cases 4 and 6 would not be able to utilise solar energy enough for it to be economically feasible for them [18].

In addition, the economy of the solar system needed to be studied in more detail to see what the investment for each household case would be. These results are stated in Table III, where due to Table II's outcome, cases 4 and 6 are excluded.
TABLE III. THE ECONOMY OF SINGLE HOUSEHOLDS PRODUCING AND USING SOLAR ENERGY

\begin{tabular}{|c|c|c|c|c|}
\hline Case & $\begin{array}{c}\text { Annual solar } \\
\text { energy } \\
\text { production }\end{array}$ & $\begin{array}{c}\text { Investment } \\
\text { required }\end{array}$ & $\begin{array}{c}\text { Economic } \\
\text { yield during } \\
\boldsymbol{I}^{\text {st }} \text { year }\end{array}$ & $\begin{array}{c}\text { Payback } \\
\text { time (a) }\end{array}$ \\
\hline 1 & $2384 \mathrm{kWh}$ & $4590 €$ & $132 €$ & 22 years \\
\hline 2 & $1617 \mathrm{kWh}$ & $3330 €$ & $90 €$ & 23 years \\
\hline 3 & $2390 \mathrm{kWh}$ & $4590 €$ & $137 €$ & 21 years \\
\hline 4 & - & - & - & - \\
\hline 5 & $3130 \mathrm{kWh}$ & $6115 €$ & $175 €$ & 23 years \\
\hline 6 & - & - & - & - \\
\hline
\end{tabular}

In Table III, for payback time, an assumption was made that the electricity price would increase by 4 per cent each year. Regardless, the payback times for each household case exceeded 20 years. The technical life of the panels is considered to be 20 to 30 years [19]. Therefore, the investment is dependent on the guarantee and durability of the solar system.

The results shown in Table III demonstrate that the total investment in solar power systems would be 18625 euros, and the revenue from the first year would be 534 euros. Furthermore, the payback time for all the systems together would be 22 years. If solar panels only function for 20 years, the internal interest rate of the return would be -1 per cent. On the other hand, if the solar panels produced energy for 30 years, the internal rate of return would be +3 per cent for the investment.

\section{B. Households sharing solar energy as a community}

The idea of the solar community would mean that the household cases in the results for Section A would invest in one larger solar system together, where they would produce electricity together. This would also mean that their consumption would be combined into one. The study for this part considers two possibilities that the community could consider.

Firstly, the combined need for the solar panels, according to Table II and III, would be $12 \mathrm{~kW}$ (cases 1,2,3 and 5). In this case, the estimated investment price for the solar panels would be 16200 euros. In total, the households with combined consumption would be able to utilise 81.7 per cent of the solar energy production. The revenue for the first year would be 579 euros, and the payback time for the investment would be 19 years. If the panels produced energy for 20 years, the internal rate of return would be +1 per cent. On the other hand, an operation time of 30 years would yield an internal interest rate of +4 per cents.

Secondly, the energy community could increase their solar panel size to $18 \mathrm{~kW}$ (cases 1 to 6 ), and still obtain a 70 per cent share of the energy utilised in the community. In this case, the investment for the system would be 23976 euros. The payback time for the investment would be 20 years, and the first year of production would produce an income of 788 euros. In terms of the internal interest rate, 20 years of production would give a return of +0 per cents. However, 30 
years of production would mean an internal rate of return of +4 per cent.

In the case of energy community, a solar power system with limited size would be more beneficial for the community, since it would be guaranteed to yield some profit for the community regardless of its length of production time.

\section{DISCUSSION}

According to the results of this study, solar energy communities could be beneficial in several ways. The economic advantage of one larger system produced 13 per cent savings in the investment price of the solar energy system. The solar energy compensation in the energy usage was 8 per cent better than in the individual household cases. Furthermore, the payback time for the investment was obtained at 3 years shorter. In addition, the maintenance of one larger unit could be assumed to be more affordable. In contrast, the disadvantages of solar energy communities are around increased transmission losses.

Moreover, there are also technical obstacles to the use of solar energy, since solar energy production digital measuring versus consumption is still technically very versatile. The system's profitability can depend on how the electricity network operator accounts for the solar system production, and how close to real life the solar production and consumption really come. [20]

The study case presented in this paper also has limitations, set by the real-life data without further analysis. The electricity consumption of the household cases during sunny seasons and daytimes has a significant bearing on the system size, investment price and overall economy of the planned solar system. In this study, the data utilised was that of real-life households that have unique consumption profiles. However, it might be plausible to modify certain consumption peaks if a household producing solar energy wanted to utilise the maximum amount of the produced solar electricity.

For instance, the majority of electrically heated households in Finland produce hot water using electric water boilers. Normally, the boilers are set to heat the water during the night, since in that way their consumption balances the day-time electricity consumption that is much more difficult to predict. If a household had very little day-time electricity consumption, the solar energy could easily be utilised for hot water production. This is just one example of energy intensive consumption that is not totally fixed to the time of the day when the system could be running. Therefore, the maximum amount of plausible consumption would require a more detailed study, where each household consumption profile was studied more in detail.

\section{CONCLUSION}

The results of this study indicate that energy communities could very well be an answer to obtaining more solar energy production in Finland. Energy communities would be economically beneficial for the households connected to them, but they would also be beneficial for the electricity system providers, since they are easier to manage. There could also be business possibilities in providing solar energy services to individual households or other private sector representatives to obtain the needed renewable energy without having a system of one's own.

The recommendation of this study is that solar energy should be made more lucrative for all private sector representatives to speed up the transition towards solar energy utilisation in Finland. Private sector representatives are ready to make the transition, but the only benefits obtained from the government are those of domestic tax reductions related to the work when the system is being installed or maintained. The swift transition towards renewable energies requires more benefits for those willing to make the transition. Furthermore, the digital monitoring of consumption, solar power production and power balance in the networks are already digitally monitored in Finland. The complicity of the electricity distribution network requires that smart grid principles and digital methods in both monitoring and consumption steering would be fully utilised and to match this new situation.

\section{ACKNOWLEDGEMENTS}

The study and results presented in this article were carried out in the Green Energy Regional Markets Development - Green ReMark (KS1024) project with funding from the European Union, the Russian Federation and the Republic of Finland (CBC 2014-2020 programme) via the Regional Council of South Karelia, Finland. We are deeply grateful for the project funding that has enabled both the study and the presentation of the results. We would also like to thank our colleagues at the South-Eastern Finland University of Applied Sciences for permitting us to use their household electricity consumption data for the study.

\section{REFERENCES}

[1] Statistics Finland 2019. Sources of energy in heat and electricity production in Finland 2017. Online electronic publication. [Cited 30.6.2019]. ISSN 1798-5072. Available (in Finnish) at: http://www.stat.fi/til/salatuo/2017/salatuo_2017_2018-1101_tie_001_fi.html

[2] P. Taalas. 2019. Climate-effect Finland?. Ilmasto-vaikutus-Suomi? Seminar presentation at Päämajasymposium 3.7.2019 in Mikkeli, Finland. Presentation material (partially in Finnish) available at: https://www.esavo.fi/resources/public/2019/Tapahtumat\%202019/Mu ut/paamajasymposium/Mikkeli\%20Taalas.pdf

[3] Directive 2018/2001 of the European Parliament and of the Council of 11 December 2018 on promotion of the use of energy from renewable sources (recast). [Cited 1.6.2019]. Available at: https://eurlex.europa.eu/legalcontent/EN/TXT/PDF/?uri=CELEX:32018L2001\&from=EN

[4] R. Tanskanen \& J. Korpijärvi. 2018.Promoting energy efficiency via renewable energy utilisation for small and medium-sized enterprises in the South Savo region Finland: Case of solar electricity. In E. Aarrevaara \& A. Harjapää (ed.). Smart Cities in Smart Regions 2018 Conference Proceedings. Lahti University of Applied Sciences publications. pp. 232-238. September 2018. Available at: http://urn.fi/URN:NBN:fi:amk-2018091815195

[5] LUT University. 2019. Solar Energy and solar electricity in Finland. Aurinkoenergia ja aurinkosähkö Suomessa. Online news. Published 27.2.2019. [Cited 13.6.2019]. Available (in Finnish) at: https://www.lut.fi/uutiset/-

/asset_publisher/h33vOeufOQWn/content/aurinkoenergia-jaaurinkosahko-suomessa

[6] Statistics Finland 2019. Statistics on energy prices in Finland 2018. [electronic publication]. ISSN: 1799-7984. Attached Figure 5. Electricity price by consumer type. Helsinki: Statistics Finland [Cited 30.6.2019]. Available (in Finnish) at: http://www.stat.fi/til/ehi/2018/04/ehi_2018_04_2019-03-

13_kuv_005_fi.html 
[7] Finnish Energy 2019. The price of electricity consists of three parts. Sähkön hinta koostuu kolmesta osasta. Online. [Cited 15.6.2019]. Available (in Finnish) at: https://energia.fi/perustietoa_energiaalasta/asiakkaat/sahkoasiakkuus/sahkon_hinta

[8] J. Ahola 2018. National Survey Report of Photovoltaic Applications in Finland 2017. Online publication. Published in September 2018. [Cited 3.6.2019]. Available at: https://www.researchgate.net/publication/327573292_National_Surve y_Report_of_Photovoltaic_Applications_in_Finland_2017

[9] M. Hokkanen. Household hourly consumption in 2018 and 2017.

[10] J. Korpijärvi. Household and summer cottage hourly electricity consumption in 2018 and 2017.

[11] T. Ranta-Korhonen. Household hourly consumption in 2018 and 2017.

[12] H. Soininen. Household hourly consumption in 2018 and 2017.

[13] R. Tanskanen. Household hourly consumption in 2018 and 2017.

[14] Finnish Energy 2019. Hourly measurements and remote readings. Tuntimittausta ja etäluentaa. Online. [Cited 4.6.2019]. Available (in Finnish) at: https://energia.fi/perustietoa_energiaalasta/asiakkaat/sahkoasiakkuus/sahkon_mittaus

[15] T. Hannula. 10.5.2019. The prices and price development of solar energy systems provided by Product Manager at Etelä-Savon Energia Ltd. Interview conducted by Dr. J. Korpijärvi.

[16] R. Tanskanen \& J. Korpijärvi. 2018. Aurinkosähkön käytön mahdollisuuksia ja kannattavuutta Etelä-Savon pk-yrityksissä. In H. Soininen \& N. Haatanen \& L. Pulkkinen (ed.). Metsä, energia ja ympäristö: Soveltavaa tutkimusta ja tuotekehitystä. Vuosijulkaisu 2018. South-Eastern Finland University of Applied Sciences publications. pp. 97-103. December 2018. Available at: http://urn.fi/URN:ISBN:978-952-344-130-9

[17] Motiva Ltd 2019. Household connected to the electricity network alternating current. Sähköverkkoon kytketty omakotitalo vaihtosähkö. Online. [Updated 8.1.2019]. [Cited 3.6.2019]. Available (in Finnish) at: https://www.motiva.fi/ratkaisut/uusiutuva_energia/aurinkosahko/enne n_jarjestelman_hankintaa/jarjestelman_kannattavuus/sahkoverkkoon_ kytketty_omakotitalo_vaihtosahko

[18] Motiva Ltd. 2019. Selling of excess electricity. Ylijäämäsähkön myynti. Online. [Updated 3.6.2019]. [Cited 3.6.2019]. Available (in Finnish)

https://www.motiva.fi/ratkaisut/uusiutuva_energia/aurinkosahko/aurin kosahkojarjestelman_kaytto/ylijaamasahkon_myynti

[19] K. Auvinen. 2015. Profitability. Kannattavuus. Online. [Published 14.9.2015]. [Cited 3.6.2019]. Available (in Finnish) at: http://www.finsolar.net/aurinkoenergian-

hankintaohjeita/kannattavuus/

[20] K. Auvinen. 2019. Problems regarding measuring - solar energy Is not often utilised by the domestic producer. Mittaustietojen laskennassa ongelma - aurinkosähkö ei usein päädykään pientuottajan hyödyksi. [Published 20.2.2019]. [Updated 12.3.2019]. [Cited 3.6.2019]. Available (in Finnish) at: http://www.finsolar.net/mittauksessa-ongelma-aurinkosahko-ei-useinpaadykaan-pientuottajan-hyodyksi/ 